Dewey and Standardization: A Philosophical Look at the Implications for Social Studies

By: Wayne Journell

Journell, W. (2007). Dewey and standardization: A philosophical look at the implications for social studies. Social Studies Research and Practice, 2(3), 301-315.

****) Social Studies Research \& Practice. Reprinted with permission. No further reproduction is authorized without written permission from Emerald Publishing. This version of the document is not the version of record. Figures and/or pictures may be missing from this format of the document. ***

Made available courtesy of Social Studies Research \& Practice: http://www.socstrp.org/.

Made available courtesy of Emerald Publishing:

http://www.emeraldgrouppublishing.com/ssrp.htm

\title{
Abstract:
}

The work of John Dewey and his beliefs regarding student-centered learning are discussed in an effort to analyze the standardization of public education with a focus on social studies instruction. Using the Virginia Standards of Learning as a model, state standards are critiqued using Dewey's views on habits and choice regarding teaching and learning. These discussions fit within Dewey's broader view that historically situates schools as an integral part of perpetuating a democratic society by providing the necessary skills that citizenship requires. As a discipline aimed at shaping future citizens by relying on critical thinking and public deliberation of issues, social studies provides an ideal medium to compare the practices of standardization to that of student-centered instruction.

Keywords: John Dewey | standardization | public education | social studies | student-centered learning | student-centered instruction

Article:

****Note: Full text of article below 


\title{
Dewey and Standardization:
}

\section{A Philosophical Look at the Implications for Social Studies}

\author{
Wayne Journell \\ University of Illinois
}

\begin{abstract}
The work of John Dewey and his beliefs regarding student-centered learning are discussed in an effort to analyze the standardization of public education with a focus on social studies instruction. Using the Virginia Standards of Learning as a model, state standards are critiqued using Dewey's views on habits and choice regarding teaching and learning. These discussions fit within Dewey's broader view that historically situates schools as an integral part of perpetuating a democratic society by providing the necessary skills that citizenship requires. As a discipline aimed at shaping future citizens by relying on critical thinking and public deliberation of issues, social studies provides an ideal medium to compare the practices of standardization to that of student-centered instruction.
\end{abstract}

John Dewey formed his educational philosophies during a progressive transition in public education that advocated student-centered learning. While the systems that Dewey observed have become antiquated, his beliefs are as relevant today as they were in the early part of the twentieth century. Dewey felt that students and their experiences should be at the center of public education with teachers acting as guides who help shape those experiences into the habits necessary for a productive citizenry. For Dewey (1916), schools are the primary instrument for shaping the nature of society. Communities and schools have a symbiotic relationship; communities set the model for society, and schools produce functioning members of that society, creating a circular flow that ensures growth of democratic ideals, economic stability, and overall American culture. 
The reliance among communities and schools has not changed from the early twentieth century, but the relationship certainly has. Dewey (1938) would find the standardization of American education to be a reversion to the "traditional schools" that he so adamantly denounces in his many works. While we live in a progressive era which protects the rights of individual students more than any other time in history, the movement to standardize education is destroying both the ability and freedom of students to think critically and creatively by forcing students to develop rudimentary habits designed simply to meet certain expectations on standardized tests. If the aforementioned symbiotic relationship that Dewey professes holds true, the United States is destined to produce a generation of individuals who have been created out of the same intellectual mold where complex issues are ignored in favor of a mass assimilation of facts.

I concur with those who argue that standardization has forced social studies teachers to abandon critical pedagogy in favor of rote instructional practices (Evans, 2001; Vogler \& Virtue, 2007). Studies have shown that incidence of student discussion in social studies classrooms has waned in the wake of high stakes assessment (Parker, 2006; Wilen, 2003). Such transformations are particularly disturbing for those advocating a liberal discourse within social studies-one that emphasizes deliberation, diversity, and reliance on student experiences (Giroux \& McLaren, 1986; Gutmann, 1987, 2004). Standards have forced social studies back to a conservative, civic republican movement that advocates nationalism and prevents educators from making decisions about curricular policy (Abowitz \& Harnish, 2006; Giroux \& McLaren, 1986; Ravitch, 2006).

I will use Deweyan philosophy to show the potential damage of standardization on public education with particular emphasis given to social studies education. Dewey's discussion of habits and his belief in the democratic aspects of schooling will serve as the basis of my critique. I will frequently refer to the Virginia Standards of Learning (SOL) as an example of how standards often restrict the creativity and critical pedagogy of social studies educators. The SOLs represent the culmination of a conservative policy movement to which the author is personally familiar, having previously taught high school social studies in the Commonwealth (Fore, 1998).

\section{Standardization and the Virginia SOLs}

No Child Left Behind (NCLB) marks the culmination of nearly twenty years of increased governmental presence in education (Mathison, Ross, \& Vinson, 2006). By the end of the 1980s, American students frequently were scoring lower on standardized assessments than other industrialized nations in math and science, prompting politicians to actively analyze public education in the United States. Their efforts resulted in the publication of Nation at Risk, a report on the substandard quality of all levels of American public education (McDonnell, 2005). Following the report, both the H.W. Bush and Clinton administrations began calling for more evidence of academic rigor and success in public education, usually resulting in the implementation of standardized tests (Cochran-Smith, 2003). Meanwhile, the shock that students in Europe and Japan were learning at a faster and more productive rate than their American counterparts caused the public to begin pointing fingers at school districts, school administrations, and teachers. As McDonnell (2005) states, "The idea of articulating welldefined content standards to which teachers are expected to teach, coupled with performance standards and assessments to measure student achievement, is a powerful idea with broad-based appeal across the ideological spectrum" (p. 35). Conservatives view standards as a way to 
promote nationalism and ensure the continuation of American international dominance while liberals laud the promise of equal educational opportunities for all students regardless of ethnicity or socioeconomic status under a standardized curriculum (Vinson, 2001).

The bipartisan push for educational accountability culminated in 2001 with NCLB. The current administration has projected that American students will be grade-level proficient in all subjects by 2012. Moreover, NCLB seeks to ensure that the majority of students cannot skew district or state results by requiring that individual schools demonstrate adequate yearly progress (AYP) in all areas of education, including demographic subgroups such as low socioeconomic, minority, or special education students. Should districts or individual schools fail to meet the requirements of NCLB in one or more of the AYP subgroups or in overall scores, they could face various sanctions ranging from the loss of federal funding to the overhauling of the district and their staffs (Rose, 2004; Ryan, 2004).

Darling-Hammond (2006) argues that this effort has backfired as white students increasingly flee from failing school districts, creating the very educational segregation that NCLB sought to eradicate. African-American and Latino students tend to score lower on standardized tests than their white counterparts, even when comparing similar income levels (Ladson-Billings, 2006). Despite the well-intentioned efforts of policy makers, standardization has failed to provide solutions to the achievement gap, other than to call attention to the already noticeable deficiencies of many urban schools in the United States (Ryan, 2004).

Under NCLB, the federal government delegates the method for quantifying public education to the individual states. Many states have adopted a series of high-stakes, end-ofcourse tests to evaluate both student achievement and teacher proficiency. Schools are assessed and labeled based on their overall student performance as well as the performance of students categorized into one or more AYP subgroups (Ryan, 2004).

The Virginia SOLs require student proficiency in a myriad of subjects, including several social studies courses, even though NCLB does not specifically require the testing of social studies for accreditation purposes (Ross, 2006). In her case study of the social studies SOL adoption process, Fore (1998) reports that the Allen administration, in power during the 1995 inception, purposefully shunned contributions from Virginia educators during the adoption debates, preferring to deal only with those advocating a likeminded conservative agenda. The end results were standards that sought teacher accountability by testing students on a mass collection of facts that followed the traditional, Euro-centered canon of American history. Despite minor revisions in 2001, the standards have maintained the same ideological tone since its inception.

SOL testing is multiple-choice and places emphasis on recall of factual information. The tests are scored on a 600 point scale with scores 400 and above considered passing. Success on SOL tests holds importance for both schools and their students. Schools with less than a 70\% SOL pass rate in any subject or among any AYP subgroup may receive sanctions or be denied accreditation by the state. Students must pass SOL tests in order to receive verified credit for courses completed during the school year. Depending on the type of diploma desired, students must accumulate a certain number of verified credits in each academic discipline in order to graduate (Yeager \& van Hover, 2006). Schools that do not maintain the standards set forth by the Commonwealth do not receive annual accreditation, and under NCLB, their students are permitted to transfer schools free of any monetary obligation. Needless to say, the demands of accreditation have put undue stress on district superintendents, building administrators, and, most of all, classroom teachers (Petersen \& Young, 2004). 


\section{Standards and Social Studies}

In addition to outlining plans for educational accountability and equality, standards offer a variety of curricular benefits. Standards provide a starting point for educators to develop instruction by expressly defining the content required for student knowledge (Ravitch, 1996). Additionally, for those who believe public schooling should instill within students basic fundamental values, standards provide a safeguard from overzealous teachers that seek to indoctrinate students with beliefs that differ from that of the community (Holmes, 2001). Despite these arguments, many educators, particularly in the highly politicized discipline of social studies, fear that standards deprofessionalize teachers and reduce complex issues into a collection of facts (Evans, 2001; Mathison et al., 2006; Vogler \& Virtue, 2007).

Ross (2006) dismisses the notion that standards have detrimentally weakened social studies instruction by making a distinction between formal and enacted curriculum. Ross sees most teachers as either "active implementers" or "user-developers" that are constantly reinterpreting and offering suggestions to policy makers while simultaneously shaping the enacted curriculum on an individual basis. Grant (2001) lends support to this notion in his study of social studies teachers working under the constraints of the New York State Regents exam. Both of the teachers studied aligned their lessons with the state standards yet maintained instructional goals that superseded the state requirements.

I argue that standards-based education presents greater influence over social studies education than Ross (2006) or Grant (2001) acknowledge. A strong body of literature suggests a formal curriculum backed by high-stakes testing manipulates pedagogical methods used in social studies instruction. In a study of high school social studies educators in Mississippi, Vogler (2005) found teachers repeatedly engaged in instructional methods designed to ensure student success on a graduation examination. Teachers admitted to using primarily rote exercises that emphasized elements of the formal curriculum. Largely absent were creative approaches to instruction, such as role playing, performance assessments, problem solving, and interdisciplinary instruction. Other studies have found similar results in states that mandate a formal social studies curriculum (Barbour, Evans, \& Ritter, 2007; Kahne, Rodriguez, Smith, \& Thiede, 2000; Segall, 2003).

A study by van Hover and Pierce (2006) nicely illustrates the negative effect of the Virginia SOLs on classroom practices. The authors monitored the progress of two first-year social studies teachers to see how the teachers responded to the pressures of SOL testing. Both teachers started the year aware but undeterred by SOL requirements, concerning themselves only with issues typical to novice teachers. However, by the end of the first semester, van Hover and Pierce observed changes in attitude and practice of the two teachers. Both teachers began grousing about the curricular pace forced upon them by SOL demands, and one teacher changed his entire teaching method, implementing frequent recitation exercises and biweekly quizzes designed to emphasize and reinforce SOL content. Yeager and van Hover (2006) document similar incidents of teachers abandoning their conceptions of social studies instruction amid mounting pressure from concerned administrators and districts over SOL requirements. These examples support the notion that American teachers view successful pedagogy as adequately preparing students for success on standardized assessments, as opposed to teachers in other nations that measure their performance based on how well students model skills taught in the classroom (Hicks, 2005). 
Such anxiety separates state standards from those offered by the National Council for the Social Studies (NCSS) and other professional organizations (Mathison et al., 2006). Many teachers remain unfamiliar with NCSS guidelines, yet they often can recite state standards nearly verbatim due to the daily self-monitoring and reflection required by high-stakes testing. As a result, the formal curriculum increasingly becomes the enacted curriculum. Standards inevitably force teachers to replace ideological concepts of instruction with survival tactics that ensure successful performance. If reputations and professionalism hang in the balance, teachers are less likely to stray from the formal curriculum and institute creative pedagogy that may be inconsistent with tested information or may deviate from valuable content instruction.

\section{The Habits of Standardization}

\section{Dewey and Habits}

Dewey (1922/1988) believes in the nature of habits when dealing with the abilities, personalities, and customs of individuals; he defines it:

[as a] kind of human activity which is influenced by prior activity and in that sense acquired; which contains within itself a certain ordering or systematization of minor elements of action; which is projective, dynamic in quality, ready for overt manifestation; and which is operative in some subdued subordinate form even when not obviously dominating activity. (p. 31)

According to Dewey (1922/1988), habits help define individuals, and the shaping of those habits is the result of the environment of the individual. Dewey views classrooms as the center of the formation of student habits with both teachers and administrators serving integral roles.

Dewey believes that habits acquired by students act as tools for their education and their post-schooling lives. For Dewey (1916), habits are not merely mindless personality quirks, rather a "means to an ends . . . an active control of the environment through control of the organs of action" (p. 46). In other words, habits are used to solve problems and dissect complex situations. As Dewey (1938) states, "The basic characteristic of habit is that every experience enacted and undergone modifies the one who acts and undergoes, while this modification affects, whether we wish it or not, the quality of subsequent experiences" (p. 35). In the context of education, the skills acquired and developed, while in school, will shape how students look at and react to the world. Therefore, schools have a tremendous responsibility for future generations of society. Habits developed during schooling do not disappear at graduation but will continue to guide the leadership and workforces of the United States. Consequently, Dewey (1909) views schools as institutions "erected by society to . . . exercise a certain specific function in maintaining the life and advancing the welfare of society" (p. 7).

Those advocating a liberal definition of social studies believe that students should develop habits that extend beyond memorization of historical facts. Classroom activities that create opportunities for students to debate issues, deliberate on potential solutions, and participate in the political process create habits of agency (Gutmann, 1987; Kahne \& Westheimer, 2006; Westheimer \& Kahne, 2004). In other words, students should prepare for future citizenship by developing the habits of good citizens. Teachers aid in this process by 
developing classroom activities that allow for critical thought and opportunities to share and deliberate ideas.

\section{The Phasing Out of Critical Thinking}

The era of NCLB has turned the goal of public education from how to think to what to think. While the difference may seem like simple semantics, Dewey (1910) believes otherwise:

If our schools turn out their pupils in that attitude of mind which is conducive to good judgment in any department of affairs in which pupils are placed they have done more than if they sent out their pupils merely possessed of vast stores of information. (p. 101)

The Virginia SOLs are very conscious of making sure that all grade levels throughout the Commonwealth are learning the same types of information, but there is no congruency about the method in which the information is taught. The standards list content from specific time periods in history but offer few ways to connect specific facts to larger themes. This creates curriculum that either functions by tedious routine or sporadic covering of content, neither of which is conducive to learning (Dewey, 1910). As Dewey (1910) argues, when teachers are given standards and the responsibility to ensure successful performance of those standards, then developing useful habits of the mind is a secondary goal. In other words, if teachers are teaching to the test, they are not developing life skills of analytical and critical thinking for their students (Anagnostopoulos, 2005; Vogler \& Virtue, 2007).

The high-stakes testing component used to quantify NCLB is not necessarily changing what students are learning but the way in which they are learning the material. There is little in the Virginia SOLs for U.S. History that would surprise the average citizen, but the amount of information needed to be covered by the end of the school year forces teachers to change their methods for analyzing historical actions, as evidenced in the studies by van Hover and Pierce (2006) and Yeager and van Hover (2006). For example, most adults remember studying Truman's decision to drop atomic bombs on Japan to end World War II. By using primary sources and discussing the reasoning behind the decision - dropping the bomb actually saved both American and Japanese lives - students could appreciate that a decision of such magnitude is not merely a means to an end that one finds in a history textbook. Students today are not consistently exposed to such arguments and debates due to the time constraints placed on teachers by standardized tests (Parker, 2006; Vogler \& Virtue, 2007). This creates an injustice much deeper than simply a poor appreciation of history. Instead, American students are not being taught to think critically about problems and are, therefore, avoiding higher levels of Bloom's taxonomy (Pattiz, 2004).

Wright (2002) defines critical thinking as "criteria [of] accuracy, clarity, plausibility, relevance, having a weight of evidence for a claim, and logic" (p. 258). For that reason, many educators scoff at the notion of having high school courses specifically designed for teaching critical thinking. This separates analytical thinking from common applications; in short, it does not create the habit of critical thinking necessary for life situations (Wright, 2002). Analytical thinking needs to be repeatedly used as a tool to solve problems in school, which will allow students to critically view social issues later in life. Dewey (1938) calls the greatest of all pedagogical fallacies the notion that "a person learns only the particular thing he is studying at the time" (p. 48). Instead, students not only learn facts or solutions to problems, but they also learn the methods and techniques used to understand such data. 
Segregation of historical facts apart from the historical process created by standardization forces students into developing a skewed perception of history. According to Dewey (1938), separating content from the process of discovery creates experiences that "[are] not available under the actual conditions of life" (p. 48). Lee (2004) concurs, claiming that students must become familiar with the historical process in order to understand that history is open to interpretation. Multiple versions of history exist; however, teachers often only expose their students to the master narrative presented in textbooks and standards. Standardization narrows the social studies curriculum, forcing teachers to implement tedious memorization techniques that only allow for the teaching of specific content (Savage, 2003). Evaluations of student knowledge have also become more simplistic. Multiple-choice and true or false assessments have taken the place of essays and projects, in part because teachers want to model what their students will see on end-of-course tests. In other words, NCLB has turned education into a rightor-wrong, black-or-white experience (Pattiz, 2004). This is especially disconcerting to social studies where human emotions and conditions are studied, creating gray areas in all aspects of history (Lee, 2004). Movements such as fascism in Germany or chattel slavery in antebellum America cannot adequately be explained as "wrong" without looking at the events and eras that led to the creation of these situations.

Students are not oblivious to this change as well. Kanevsky and Keighley (2003), in an attempt to understand academic discouragement, conducted a study of middle and high school students who were labeled as gifted and talented in elementary school but were academically underachieving in their secondary years. The students surveyed targeted their boredom at the techniques of their teachers, specifically "copying, memorizing, regurgitating, repetition [and] waiting." (p. 21). One student reported, "I remember always thinking I want to learn something and we're not learning anything and we did the same things over and over again." (p. 20). Another telling response was, "The only thing you do at school is memorize ... They don't expect you to understand." (p. 24).

Chiodo and Byford (2004) performed a similar study solely for the field of social studies, using eighth and eleventh grade history students. The authors found negative attitudes towards social studies with students referring to their history courses as "dull, boring, and irrelevant," due to instruction based on lecture and worksheets (p. 16). The eighth-grade students preferred their social studies courses to involve more "group projects, group work, debates, and simulations," activities which are often stifled by standardization (p. 20). As any educator knows, when the enjoyment is taken out of learning, students will find other ways to focus their motivation. More importantly, even though the students in both studies did not use Deweyan terminology, they saw the habits being forced upon them as detrimental to their education. They knew that the superficial techniques of their teachers were hiding a deeper understanding of the subject.

As a former high school teacher in Virginia, I had a perfect student pass rate on the Virginia SOL tests for U.S. History and World History Part II during the 2004-2005 school year. While my school principal and district supervisors were thrilled with my results, I felt that my history students did not receive as beneficial an education as my Advanced Placement Government students, who were free from an end-of-course SOL testing requirement. In the government course, I had the freedom to cover material without the restraints of time or pressure. My students engaged in advanced levels of thinking such as student-lead classroom discussions and oral debates on controversial issues. The course was demanding, but at the end of the year, nearly half of my students told me that government was the most rewarding course they had taken in high school, because they learned about themselves, both personally and politically, and 
that the class had forced them to perform a variety of tasks that they had never before attempted. The course instilled new habits in those students, such as formulating arguments and public speaking, both of which will remain useful to them in their academic and professional careers.

Unfortunately for my history students, their educational experience was limited due to the constant pressure to cover the required standards before the end-of-course test, similar to the aforementioned studies by van Hover and Pierce (2006), Vogler (2005), and Yeager and van Hover (2006). Their courses were dominated by worksheets, lectures, and repetition of facts - a true Machiavellian method where the ends justified the means. Dewey (1910) warns against using such techniques in the teaching of history:

The danger in those studies where the main emphasis is upon acquisition of skill is just the reverse. The tendency is to take the shortest cuts possible to gain the required end. This makes the subjects mechanical and thus restrictive of intellectual power. (p. 51)

One could argue that my history and government students will likely forget most of the content of their respective courses as they reach adulthood, but my government students may remember those habits of formulating arguments and effective public speaking. As Dewey (1938) states, "Collateral learning in the way of formation of enduring attitudes, of likes and dislikes, may be and often is much more important than the spelling lesson or lesson in geography or history that is learned" (p. 48). Consider a sports analogy: A baseball player with any remote skill can face a hard-throwing pitching machine and eventually learn to hit the ball consistently, because the motion of the machine and the speed and location of the pitches will remain constant. All the hitter has to do is adjust his timing. Of course, replace the machine with a hard-throwing pitcher and suddenly the batter flails hopelessly. While the speed is similar to that of the machine, the movement of the ball and the release point of the pitcher are going to vary with each pitch. Therefore, having a player learn to hit exclusively off of a pitching machine is ineffective, because it creates poor habits and the hitter is unable to adjust when minor variances are implemented. Instead, a more effective technique would be to equip the hitter with basic habits of hitting such as keeping one's eye on the ball, maintaining a solid base, and using a level swing. The same philosophy holds true for students: Teach them the tools necessary to learn and they will be able to learn in a multitude of environments.

\section{Habits that Discourage the Love of Learning}

Garrison (2004) asserts that the "ultimate goal [of education] is to become a lover of wisdom" where "wisdom . . . is beyond knowledge alone though knowledge is a means to its attainment" (p. 147). Such a phrase is rich with Dewey, who believes that the most important habit that educators can impress upon youth is the love of learning. Dewey (1922/1988) views habits as arts that that lead to the betterment of individuals and society. It is here that one finds the crux of Dewey's feelings about habits, that they "are so intimately a part of ourselves" ( $p$. 21). No other aspect of who we are as individuals is as directly related to our environment as the habits that we form. As Dewey acknowledges, some habits can be damaging and virtually irremovable, but that is due to the intense bond that we have with those habits. People fall victim to oppressive habits such as drinking and smoking, and a cunning marketer will understand that a great amount of money is available in the treatment and cures of such addictions because those habits become fundamental to the identity of an individual. 
A positive habit will have the opposite outcome. Someone who gains the habits of critical thinking and intrinsic love of knowledge will experience riches that never cease. Dewey (1910) calls this phenomenon abstract thinking or "interest in intellectual matters for their own sake, a delight in thinking for the sake of thinking" (p. 141). Standardization has created an outcomebased society that starts at the ground level. Every assignment a student attempts to complete requires value, a score or an evaluation that signifies accomplishment or successful completion. Even among more motivated, college-bound students remains a desire to learn for the purposes of a reward. In my Advanced Placement course, I assigned weekly readings of a philosophical nature on the structure and efficiency of the American political system and occasionally gave remedial pop quizzes to assess both the effort and comprehension of my students. At one point, I overheard something I had never expected: an admonished student griping about not being quizzed because they had actually read the assigned material. Where was the elation that accompanies learning new knowledge or the excitement of opening new possibilities that had previously ceased to exist? When people learn for the sake of others, they lose focus of the individual for whom learning is truly designed.

Learning does offer retribution as long as the value is intrinsically motivated. True learning is the key that unlocks doors and opens hidden passageways to the unexplored. Dewey (1910) believes that "thought affords the sole method of escape from purely impulsive or purely routine action" (p. 14). When education becomes standardized and states dictate both the knowledge presented and the method of thought that accompanies that knowledge, then states limit students' ability to escape, not only from the monotony of the classroom, but also from the boundaries impressed upon them by societal customs. Dewey $(1910,1916)$, using Plato's definition of slavery, would view such forced habits as a form of oppression. Shackles of iron are simply replaced by stocks of routine, repetition, and irrelevance. Similar to the way slave narratives tell of African Americans using education as a way to escape from bondage, students need the habits of critical thinking and intrinsic learning to break away from the darkness of unimaginative, simplistic thought. In essence, the argument against standardization is a plea for freedom.

\section{Standardization as Oppression of Individuality}

\section{Students as Individuals}

In this era of special education, IEPs, and 504 plans, it almost seems asinine for anyone to question the individuality of public education. Using those parameters, it could easily be argued that we currently live in the most individualized educational system in history. Indeed, great pains have gone into ensuring that schools cater to the learning styles of individual students by modifying instructional strategies to meet intellectual or physical exceptionalities. Dewey (1938) recognizes the need for individualism in education:

[Not] every pupil will respond or that any child of normally strong impulses will respond on every occasion. There are likely to be some who, when they come to school, are already victims of injurious conditions outside of the school and who have become so passive and unduly docile that they fail to contribute... The teacher has to deal with [those students] individually. (p. 56) 
Even in an era prior to modern classifications of student exceptionalities, Dewey understood that all students learn differently and would suffer from the social Darwinian style used in the early part of the last century.

While Dewey would approve of the steps taken to promote individuality regarding how students learn, he would be horrified at the methods the state has taken to regulate what students learn. In many ways, our public schools have regressed to the traditional schools that Dewey (1938) admonishes in his writings. One of the innate flaws of the traditional schools was that they "consisted of subject-matter that was selected and arranged on the basis of judgment of adults as to what would be useful for the young... material to be learned was settled upon outside of the present life-experience of the learner" (p. 76). Dewey sees a much stronger purpose in education which is to "prepare the young for future responsibilities and for success in life, by means of acquisition of the organized bodies of information and prepared form of skill which comprehend the material of instruction" (p.18). He views strict implementation of educational policy from higher authorities as oppressive to "expression and cultivation of individuality" ( $p$. 19).

\section{Limitation of Student Choice}

Forgoing a debate on the reality of NCLB, one can easily see the problem with the current system, which operates with the underlying assumption that all students should strive to go to college. Once again, this dilemma is not unique to our current time and place. Dewey realized that preparing students for life and college were two very different endeavors (Reid, 2002). As Dewey (1916) states, "a society to which stratification into separate classes would be fatal, must see to it that intellectual opportunities are accessible to all on equable and easy terms" (pp. 87-88).

Dewey paraphrases Plato when he states that "the business of education [is] to discover what each person is good for, and to train him mastery of that mode of excellence" (p. 309). Sadly, standardization is forcing schools to phase out programs designed to promote individuality and self-exploration. Many school districts have had to cut funding for art, music, theatre, vocational education, and other electives to budget for remediation programs for students who did not pass one or more of their standardized assessments. Students unsuccessful in the eyes of NCLB are being pulled out of elective courses and forced to participate in even more repetitious remediation, when many of those same students were finding their passion in those specialty classes (Darling-Hammond, 2004; Ryan, 2004).

Even within social studies, standards place value on certain subjects over others. In Virginia, all secondary social studies courses require end-of-course SOL assessments except U.S. and Virginia government. It seems absurd that the Commonwealth would require that students demonstrate proficient knowledge about ancient world history but not about the government in which they live. If Dewey were to endorse any form of standardization, one could argue that he would support testing students about the role of government before they became active citizens of a democracy. As Dewey (1916) states, "A government resting on popular suffrage cannot be successful unless those who elect and who obey their governors are educated" (p. 87). The fact that standardization exists in Virginia, yet knowledge of American government is not overtly required, is perhaps the most democratic argument one can make in favor of reforming the SOLs. 


\section{The Effect of Standardization on Teachers}

The individual restrictions placed on students through standardization only tell part of the story. The art of teaching is also suffering by limiting topics available for discussion and by forcing teachers to focus their attention more on content than their students' performance. Dewey (1916) agrees, maintaining that teachers, "when engaged in the direct act of teaching, [need] to have subject matter at [their] fingers' ends; [their] attention should be upon the attitude and response of the pupil" (p. 183). In other words, the subject matter that state standards stringently attempt to drill into students should simply be tools for the greater end of allowing students to feel passionately about issues. When vibrant issues are deadened through habits of simple regurgitation, both student and teacher lose interest in the learning process.

Dewey (1916) continues by stating, "The teacher should be occupied not with the subject matter in itself but in its interaction with the pupils' present needs and capacities" (p. 183). Standardization has become so stifling, especially as the popularity of merit pay continues to grow, that standards often act as blinders, keeping teachers from observing the needs of their classroom (van Hover \& Pierce, 2006). Good teachers know that the pulse of a classroom cannot be found in a manual but rather in the eyes and responses of their students. When an issue is greeted with blank stares of bewilderment or multiple questions of the same nature then astute teachers know that reteaching is necessary. Standardization forces teachers to plow through curriculum, knowing that they have to meet a deadline by the end of the year. The assumption is that if students did not completely understand one issue, they will comprehend subsequent issues, and by the assessment date, they will know enough to ensure success. This results in a watered-down curriculum where students are left with gaping holes in content (Anagnostopoulos, 2005).

In a subtle way, the Virginia SOLs are attempting to censor teachers and students through the required information for various disciplines, particularly in the often politicized area of social studies, a phenomenon Fore (1998) details in her study. For example, the SOLs for U.S. History only make passing reference to Watergate. One may quickly assume that the course ends before the 1970s for the sake of brevity, but under closer examination, the SOLs acknowledge Reagan's role in ending the Cold War and the groundbreaking achievements of Sandra Day O'Connor and Sally Ride, all of which occurred well after Nixon's disgraceful exit from the Presidency. The SOLs even mention Nixon's Vietnaminzation plan and opening of relations with China. Of course, being a traditionally Republican state, the architects of the Virginia SOLs may have downplayed the significance of Watergate for political benefit. A quick glance at the curriculum guide shows that the same clemency was neglected when discussing Lyndon Johnson and his failures in Vietnam.

Any student of history knows that Watergate changed the role of the Presidency as we know it today, and its omission from an American history course is preposterous regardless of political affiliation. Obviously, legislators are doing a disservice to their young constituents when they deprive them of knowledge, but these same legislators are also putting their teachers in a bind. Do teachers attempt to include omitted issues such as Watergate into the curriculum even when they know it will not be tested? The opportunity cost of such a decision is huge for an educator in this modern era. Taking a couple days to discuss Watergate means less time for covering the Cold War or the Civil Rights Movement, both of which are subject for the end-ofcourse SOL test. Teachers are then pushed into a moral dilemma: What is best for their students - learning about an issue important to American history and culture, or hammering 
home pre-approved issues in the off chance that they may be the subject of the question that makes or breaks a student on their end-of-course assessment? Unfortunately, I feel that most teachers choose the latter, because they are concerned about the final scores associated with individual merit and school accreditation.

\section{Conclusion}

According to a popular maxim, what is old will soon become new again. Dewey's student-centered philosophies have passed the test of time and are receiving renewed attention due to the debilitating effects standardization is having on both teaching and learning. In particular, standardization reduces social studies, a discipline built upon analytical thought and debate, to a process of recitation and memorization. While Dewey may have approved of ensuring that students enter adulthood with a basic set of knowledge, he would have never approved of such knowledge coming at the expense of critical pedagogy relevant to students' interests. As Dewey (1910) reiterates throughout his works, learning how to think better equips students for future endeavors than simply focusing on what to think. The same sentiment applies to social studies. Understanding the processes of historical thought and the value of deliberating social issues will benefit students more than amassing trivial facts. In order to achieve these goals, teachers must tailor curriculum to students' experiences and interests. A set curriculum deprives both teachers and students of creativity and autonomy in the classroom. A Deweyan model would circumvent the stifling effects of standardization, while continuing to provide a rigorous curriculum. A student-centered approach forces student ownership over his or her personal learning by increasing intrinsic motivation.

As Dewey (1910) states, "Thought affords the sole method of escape from purely impulsive or purely routine action" (p. 14). When students are deprived of the ability to think, states run the risk of turning their future citizenry into automatons incapable of analytical thought. If, as Dewey (1916) believes, society rests on the success or failure of public education, future decisions on standardization may affect more than social studies: American democracy may well be at stake.

\section{References}

Abowitz, K.K., \& Harnish, J. (2006). Contemporary discourses of citizenship. Review of Educational Research, 76, 653-690.

Anagnostopoulos, D. (2005). Testing, tests, and classroom texts. Journal of Curriculum Studies, 37, 35-63.

Barbour, M., Evans, M., \& Ritter, J. (2007). Situating the Georgia performance standards in the social studies debate: An improvement for social studies classrooms or continuing the whitewash. Journal of Social Studies Research, 31(1), 27-33.

Chiodo, J.J., \& Byford, J. (2004). Do they really dislike social studies? A study of middle school and high school students. Journal of Social Studies Research, 28(1), 16-26.

Cochran-Smith, M. (2003). The unforgiving complexity of teaching: Avoiding simplicity in the age of accountability. Journal of Teacher Education, 54(1), 3-5.

Darling-Hammond, L. (2004). Standards, accountability, and school reform. Teachers College Record, 106, 1047-1085. 
Darling-Hammond, L. (2006). Securing the right to learn: Policy and practice for powerful teaching and learning. Educational Researcher, 35(7), 13-24.

Dewey, J. (1909). Moral principles in education. Carbondale: Southern Illinois University Press.

Dewey, J. (1910). How we think. Mineola, NY: Dover Publications.

Dewey, J. (1916). Democracy and education. New York: Free Press.

Dewey, J. (1922/1988). Human nature and conduct. In J.A. Boydston (Ed.), John Dewey: The middle works, 1899-1924, Volume 14. Carbondale: Southern Illinois University Press.

Dewey, J. (1938). Experience and education. New York: Touchstone.

Evans, R.W. (2001). Thoughts on redirecting a runaway train: A critique of the standards movement. Theory and Research in Social Education, 29, 330-339.

Fore, L.C. (1998). Curriculum control: Using discourse and structure to manage educational reform. Journal of Curriculum Studies, 30, 559-576.

Garrison, J. (2004). Dewey and the education of Eros: A critique in the ideal of self creation. JCT, 20, 147-161.

Giroux, H.A., \& McLaren, P. (1986). Teacher education and the politics of engagement: The case for democratic schooling. Harvard Educational Review, 56, 213-238.

Grant, S.G. (2001). An uncertain lever: Exploring the influence of state-level testing in New York State on teaching social studies. Teachers College Record, 103, 398-426.

Gutmann, A. (1987). Democratic education. Princeton: Princeton University Press.

Gutmann, A. (2004). Unity and diversity in democratic multicultural education: Creative and destructive tensions. In J.A. Banks (Ed.), Diversity and citizenship education: Global perspectives (pp. 71-96). New York: Jossey-Bass.

Hicks, D. (2005). Continuity and constraint: Case studies of becoming a teacher of history in England and the United States. International Journal of Social Education, 20(1), 18-51.

Holmes, M. (2001). Education and citizenship in an age of pluralism. In D. Ravitch \& J.P. Viteritti (Eds.), Making good citizens: Education and civil society (pp. 187-212). New Haven: Yale University Press.

Kahne, J., Rodriguez, M., Smith, B., \& Thiede, K. (2000). Developing citizens for democracy? Assessing opportunities to learn in Chicago's social studies classrooms. Theory and Research in Social Education, 28, 311-338.

Kahne, J., \& Westheimer, J. (2006). Teaching democracy: What schools need to do. In E.W. Ross (Ed.), The social studies curriculum: Purposes, problems, and possibilities ( $\left.3^{\text {rd }} \mathrm{ed}.\right)$ (pp. 297-316). Albany: State University of New York Press.

Kanevsky, L., \& Keighley, T. (2003). To produce or not to produce? Understanding boredom and the honor in underachievement. Roeper Review, 26, 20-28.

Ladson-Billings, G. (2006). From the achievement gap to the education debt: Understanding achievement in U.S. schools. Educational Researcher, 35(7), 3-12.

Lee, P. (2004). Understanding history. In P. Seixas (Ed.), Theorizing historical consciousness (pp. 129-164). Toronto: University of Toronto Press.

Mathison, S., Ross, E. W., \& Vinson, K. D. (2006). Defining the social studies curriculum: Influence of and resistance to curriculum standards and testing in social studies. In E. W. Ross (Ed.), The social studies curriculum: Purposes, problems, and possibilities $\left(3^{\text {rd }} \mathrm{ed}.\right)$ (pp. 99-114). Albany: State University of New York Press.

McDonnell, L.M. (2005). No Child Left Behind and the federal role in education: Evolution or revolution. Peabody Journal of Education, 80(2), 19-38. 
Parker, W.C. (2006). Public discourses in schools: Purposes, problems, possibilities. Educational Researcher, 35(8), 11-18.

Pattiz, A.E. (2004). The idea of history teaching: Using Collingwood's idea of history to promote critical thinking in the high school history classroom. The History Teacher, 37, 239-249.

Petersen, G.J., \& Young, M.D. (2004). The NCLB act and its influence on current and future district leaders. Journal of Law and Education, 33, 343-363.

Ravitch, D. (1996). The case for national standards and assessments. The Clearing House, 69, 134-135.

Ravitch, D. (2006). Should we teach patriotism? Phi Delta Kappan, 87, 579-581.

Reid, W.A. (2002). The educational situation as concerns secondary education: Thoughts on the thoughts of John Dewey. Journal of Curriculum and Supervision, 17, 130-143.

Rose, L.C. (2004). No child left behind: The mathematics of guaranteed failure. Educational Horizons, 82, 121-130.

Ross, E.W. (2006). The struggle for the social studies curriculum. In E.W. Ross (Ed.), The social studies curriculum: Purposes, problems, and possibilities $\left(3^{\text {rd }}\right.$ ed.) (pp. 17-36). Albany: State University of New York Press.

Ryan, J.E. (2004). The perverse incentives of the No Child Left Behind act. New York Law School Review, 79, 932-982.

Savage, T.V. (2003). Assessment and quality social studies. The Social Studies, 94, 201-206.

Segall, A. (2003). Teachers' perceptions of the impact of state-mandated standardized testing: The Michigan Educational Assessment Program (MEAP) as a case study of consequences. Theory and Research in Social Education, 31, 287-325.

van Hover, S., \& Pierce, E. (2006). "Next year will be different": Two first-year history teachers' perceptions of the impact of Virginia's accountability reform on their instructional decision-making. Journal of Social Studies Research, 30(2), 38-50.

Vinson, K.D. (2001). Image, authenticity, and the collective good: The problematics of standards-based reform. Theory and Research in Social Education, 29, 363-374.

Vogler, K.E. (2005). Impact of a high school graduation examination on social studies teachers' instructional practices. Journal of Social Studies Research, 29(2), 19-33.

Vogler, K.E., \& Virtue, D. (2007). "Just the facts ma'am": Teaching social studies in the era of standards and high-stakes testing. The Social Studies, 98, 54-58.

Westheimer, J., \& Kahne, J. (2004). What kind of citizen? The politics of educating for democracy. American Educational Research Journal, 41, 237-269.

Wilen, W.W. (2003). Conducting effective issue-based discussions in social studies classrooms. International Journal of Social Education, 18(1), 99-110.

Wright, I. (2002). Challenging students with the tools of critical thinking. The Social Studies, 93, 257-261.

Yeager, E.A., \& van Hover, S. (2006). Virginia vs. Florida: Two beginning history teachers' perceptions of the influence of high-stakes tests on their instructional decision-making. Social Studies Research and Practice, 1, 340-358. 